\title{
DIMINISHING SEISMIC EFFECT ON BUILDINGS USING BEARING ISOLATION
}

\author{
A. B. M. SAIFUL ISLAM \\ Department of Civil \& Construction Engineering, \\ College of Engineering, Imam Abdulrahman Bin Faisal University, \\ Dammam 31451, Kingdom of Saudi Arabia. \\ "Corresponding author: asislam@iau.edu.sa
}

(Received: $17^{\text {th }}$ May 2017; Accepted: $28^{\text {th }}$ Feb 2018; Published on-line: $1^{\text {st }}$ June 2018)

https://doi.org/10.31436/iiumej.v19i1.844

\begin{abstract}
Adopting suitable seismic protection techniques is presently a foremost concern worldwide and has become a governing principle in the growing construction industry globally. Thus, a rapid upsurge in infrastructure development in seismic-prone areas requires proper treatment for building structures. Therefore, the aim of the study is to incorporate a rubber bearing isolation device in a building base in order to diminish the seismic effect on the superstructure. The changes of structural parameters and responses of fixed-based buildings for applying High Damping Rubber Bearing (HDRB) are investigated under site-specific ground excitation. Twenty representative buildings have been used to examine the responses employing four types of HDRB systems. The study reveals that the HDRB makes the structure more flexible, offering reduced structural responses. The introduction of HDRB may help to decrease floor moment by $31 \sim 55 \%$, which can allow the structures to withstand comparatively high seismic tremors safely and efficiently. The base isolated structures experience significant lateral shift between 87.15 and $130.15 \mathrm{~mm}$, and relative floor displacement is below $3 \%$ because of additional flexibility. The effective inertia height for the BI buildings remains under twothirds of building elevation showing triangular distribution concentrating to the top story level. The reduction in forces, moments, and relative displacements of the structural members by applying HDRB can ensure economic design and higher structural safety against seismic excitation.
\end{abstract}

ABSTRAK: Penerapan teknik yang sesuai bagi pelindungan gelombang seismos menjadi penekanan semasa di seluruh dunia dan telah menjadi prinsip penentu dalam industri pembinaan secara global. Oleh itu, kenaikan yang cepat dalam pembangunan infrastuktur dalam kawasan terdedah kepada gelombang seismos memerlukan penyelenggaraan yang betul bagi struktur bangunan. Jadi, matlamat kajian ini adalah bagi menggabungkan getah alat pengandar asing dalam teras bangunan bagi mengurangkan kesan seismos pada struktur asas. Perubahan pada parameter struktur dan tindak balas tapak-tetap bangunan bagi penggunaan teknik High Damping Rubber Bearing (HDRB) dikaji di bawah setiap kenaikan getaran gelombang sebenar bawah tanah. Dua puluh bangunan telah digunakan bagi menilai tindak balas terhadap penggunaan empat jenis sistem HDRB. Kajian menunjukkan HDRB membuatkan struktur lebih fleksibel, dan mengurangkan tindak balas terhadap struktur. Penggunaan HDRB dalam pembangunan membantu mengurangkan momen lantai sebanyak 31 55\%, di mana struktur bangunan lebih tahan terhadap gegaran tinggi secara selamat dan berkesan. Struktur asas yang terasing mengalami peralihan sisi yang ketara antara 87.15 dan $130.15 \mathrm{~mm}$, dan anjakan lantai relatif di bawah 3\% dengan penambahan sistem fleksibel ini. Ketinggian inertia berkesan bagi bangunan BI kekal di antara dua pertiga ketinggian bangunan. Ini menunjukkan pengagihan segitiga tertumpu pada aras atas bangunan. Pengurangan pada 
daya, momen dan perubahan relatif struktur menggunakan HDRB dapat memastikan reka bentuk lebih ekonomi dan selamat pada bangunan tinggi daripada sebarang gelombang seismos.

KEYWORDS: bearing isolation; high damping rubber bearing; seismic prone building; structural flexibility

\section{INTRODUCTION}

Earthquakes are sudden and overwhelming natural calamities. During earthquakes, extreme ground motion may cause severe damage to structures. The vulnerability of structures to seismic damage has been highlighted by numerous recent earthquakes worldwide. They cause inertia forces on the building structures that are a function of ground accelerations induced by the earthquake and the building mass. When the ground movement accelerates, the strength of the structure must be augmented to prevent the structural damage. However, continuous increase of building strength is not a practical way to solve the issue. It is neither easy nor economic to design seismic-prone buildings for such strength levels. Conversely, instead of increasing the strength capacity, seismic base isolation can give a potential solution by reducing the structural responses. Though the occurrence of a natural earthquake cannot be controlled, its influence on structures can be diminished by separating superstructures from their foundations. The isolation system provides additional flexibility as well as energy dissipation capability by offering such separation [1]. A new generation device, the high damping rubber bearing (HDRB), has brought an innovative aspect for analyzing and designing base isolated (BI) structures [26]. The HDRB rheology model [7], mechanical models [8] and the stiffening importance of HDRBs [9] are some of the investigations done to predict structural responses of BI buildings.

Even though the use of isolators is well known, there is a lack of appropriate research on the efficient practical implementation of high damping rubber bearing devices. The actual in-situ earthquake simulations have rarely been done because of lengthy analysis for dynamic response and expensive computation process. Due to advancements in computer software and hardware, it has become relatively easier to conduct the numerical investigation [10] precisely.

Therefore, the present study evaluates the viability of using rubber bearing isolation devices, HDRB, at the base of the buildings and evaluates its effect on superstructure. Static and dynamic analyses have been carried out inserting isolators for different configurations of the structures. Design parameters of the isolators required for the selected buildings are assessed. Moment and displacement behavior of fixed base (FB) and BI buildings have been evaluated. Furthermore, the effective height of inertia forces has been appraised.

\section{MATERIALS AND METHODS}

\subsection{Idealization of Building Frames}

Reinforced concrete (RC) multi-storied building frames with plan areas and elevations, as shown in Fig. 1, are modelled. Four moment resisting frame (MRF) buildings of 4 bays@7.62m at x and y directions comprising story height @3.05m with gradual increase of numbers of stories to 4 (four), 6 (six), 8 (eight) and 10 (ten) have been chosen. For each building, the total seismic weight is disseminated in equal manner over 
all the floors. Static analyses are carried out initially to get the required loading for the isolation design. For the conventional state, the building natural time periods are 0.50 (4 Story), 0.75 (6 Story), 0.80 (8 Story) and 1.00 (10 Story). Four types of HDRB system have been used for all the buildings leading to a total number of 16 scenarios. Base isolators are designed and evaluated for all the four variations of the studied building. The isolators are attached at the base level confirming all the properties. The building structures without and with HDRB are also analyzed for dynamic responses by using SAP2000 [11].

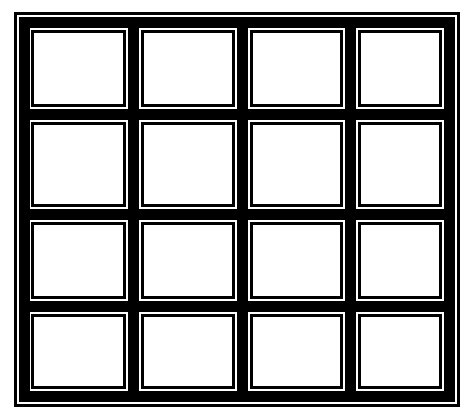

(4@7.62 m bay both ways)

Fig. 1: Plan of the selected multi-storied buildings.

\subsection{Design of HDRB}

In this study, the HDRB isolators have been designed according to the procedure mentioned by Kelly et al. [12]. A computer code, HDRB-NONLIN, has been produced to design HDRB iteratively. The code requires initial input of total seismic weight, dimension of bearing, and number and thickness of bearing layers. The high initial stiffness, post elastic stiffness, effective damping, yield strength, as well as post yield stiffness ratio of the isolation device are computed using this code. The bearings are attached at the bottom of every column defining these parameters in the analysis package. The flow chart in Fig. 2 shows the sequential process of designing HDRB. For smaller dimensions, HDRB offers higher shear strain. Because of large vertical stiffness, HDRB can withstand substantial structural loads [13]. The characteristics of materials and parameters for designing the HDRB isolators are given in Table 1. The HDRBs are demarcated by the circular shape, size of its plan, configurations of rubber layers, as well as steel plates.

Table 1: Salient features of HDRB.

\begin{tabular}{ccc}
\hline Elastomer Properties & Unit & Value \\
\hline Modulus of elasticity & $\mathrm{KPa}$ & 1350 \\
Shear Modulus & $\mathrm{KPa}$ & 400 \\
Material Constant, $\mathrm{k}$ & --- & 0.87 \\
Ultimate Elongation & $\%$ & 650 \\
\hline Designed parameter & & \\
\hline Shape & --- & Circular \\
No. of bearings & --- & 25 \\
Diameter of bearing & $\mathrm{mm}$ & 950 \\
Thickness of rubber layer & $\mathrm{mm}$ & 10 \\
Height of cover plate & $\mathrm{mm}$ & 40 \\
\hline & &
\end{tabular}




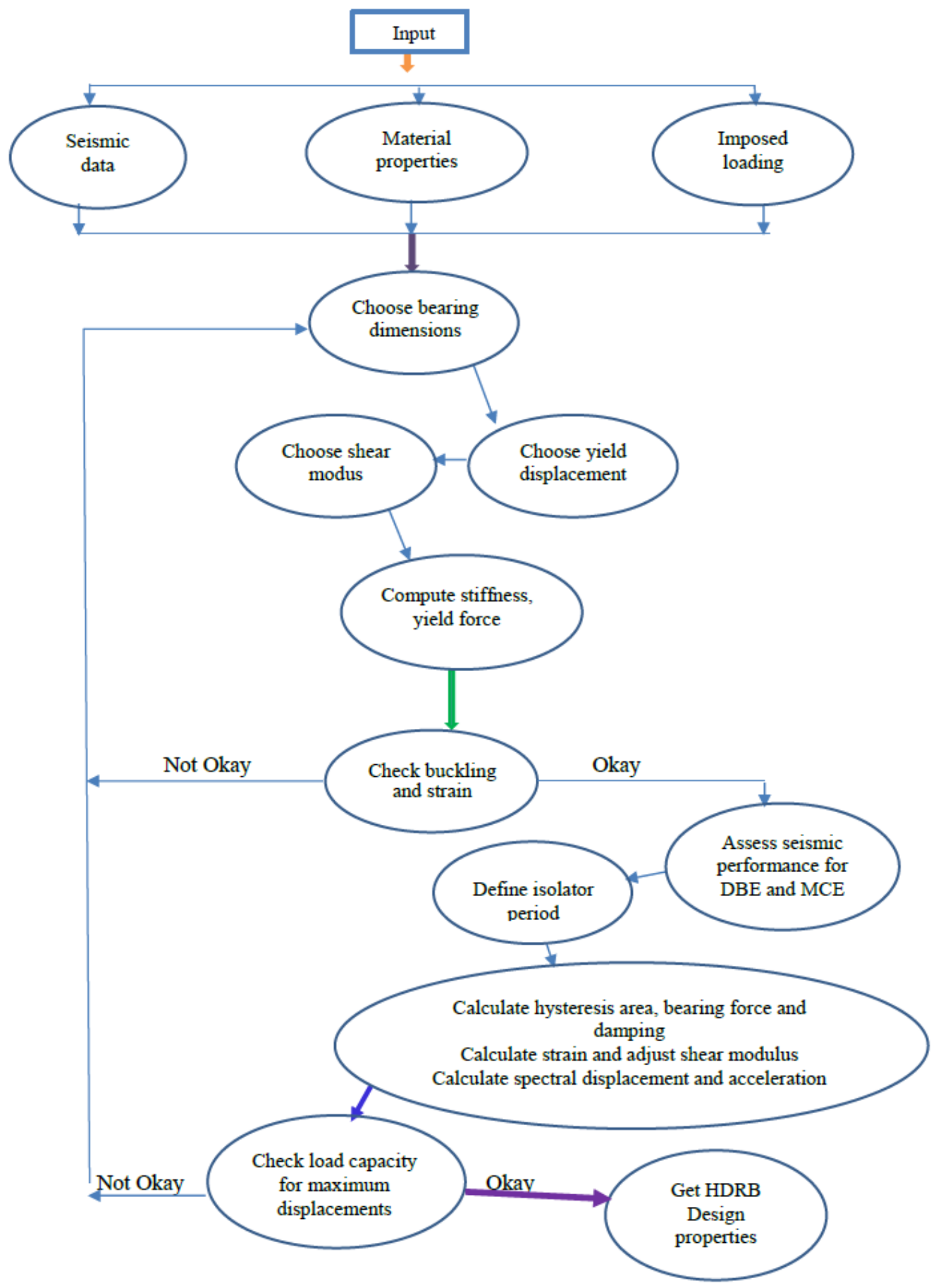

Fig. 2: Flow chart of HDRB design.

Damping has been varied for different bearings. The characteristics of the bearings are given in Table 2. The HDRB is assigned to the building columns' base. The bearings contain alternating layers of high damping rubber in thin layers and steel plates. The low shear modulus of the elastomers controls the bearing's horizontal stiffness. Furthermore, high vertical stiffness is the contribution of steel plates which obviously preclude rubber bulging. Lower horizontal stiffness of HDRB devices ensures the natural periods to be higher. High non-linearity of stiffness and energy dissipation is the salient behavior of HDRB, which is shear strain dependent. 
Table 2: Bearing characteristics

\begin{tabular}{ccccc}
\hline $\begin{array}{c}\text { Bearing } \\
\text { Device }\end{array}$ & $\begin{array}{c}\text { Period of } \\
\text { Isolator }(\mathbf{s e c})\end{array}$ & $\begin{array}{c}\text { Damping } \\
\mathbf{( \% )}\end{array}$ & $\begin{array}{c}\text { Initial lateral } \\
\text { Stiffness }(\mathbf{K N} / \mathbf{m m})\end{array}$ & $\begin{array}{c}\text { Post-elastic } \\
\text { stiffness }(\mathbf{K N} / \mathbf{m m})\end{array}$ \\
\hline HDRB1 & 1.5 & 15 & 11.085 & 3.034 \\
HDRB2 & 2.0 & 16 & 10.977 & 2.452 \\
HDRB3 & 2.5 & 17 & 10.932 & 2.001 \\
HDRB4 & 3.0 & 19 & 10.921 & 1.557 \\
\hline
\end{tabular}

\subsection{Model of HDRB}

The effective horizontal stiffness of HDRB is contemplated in terms of $K_{r}$. Equivalent viscous damping is employed. The bearing's force-deformation has been considered in the modelling as equivalent to linear. The shape of force-deformation of HDRB under loading is shown in Fig. 3. The post elastic stiffness has been derived as Eqn. (1).

$$
K_{r}=\frac{G_{\gamma} A_{r}}{T_{r}}
$$

The hysteresis loop area obtained for the respective shear modulus and equivalent viscous damping provides the hysteresis loop area. The parameter shear modulus, $G_{\gamma}$ is a function of shear strain. The unloading stiffness is named elastic stiffness, $K_{u}$ and is defined by Eqn. (2).

$$
K_{u}=K_{r}
$$

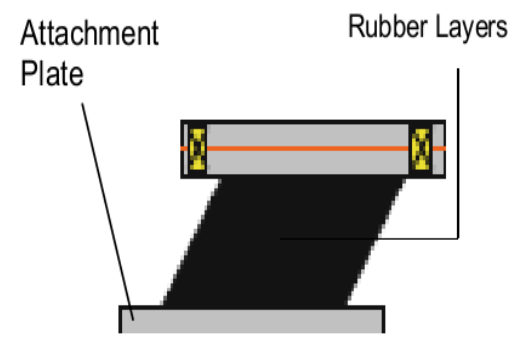

Fig. 3: Deformation pattern of HDRB (not to scale).

The force intercept, Q, follows the Eqn. (3), which is estimated from effective stiffness, damping $\beta_{\text {eff }}$, maximum displacement $\Delta$ and yield displacement $\Delta_{y}$ [14].

$$
Q=\pi \beta_{\text {eff }} * K_{r} * \Delta^{2} /\left(\left(2-\pi \beta_{\text {eff }}\right) * \Delta-\Delta_{y}\right)
$$

\subsection{Structural Analysis}

Simple linear static analyses have been performed with minimum complexity. The lateral loads for ground excitation are obtained using structural parameters such as modification factor response, seismic zone factor, soil profile, etc. In addition to this, the lateral shear force imposed by wind loading has been determined from the related coefficients and code requirements for earthquake and wind analysis that follow the code UBC 1997 [15]. The prototype buildings have been simulated and loaded in the finite element package. The equivalent static analysis considers $R_{I}=8.0$ for the traditional FB buildings. On the other hand, a reduced response modification factor of $R_{I}=2.0$ has been 
considered for the BI buildings with the structural coefficient of 1.0 [15] as per the occupancy.

Dynamic analysis has been carried out using the response spectrum analysis (RSA). The FB structures are investigated by RSA along with the equivalent static analysis. The structures are then linked to the isolator system and such BI structures are analyzed by RSA to predict the dynamic behavior. The site-specific Dhaka earthquake seismic record, generated from the recent nearby earthquake occurrence of 2009, has been chosen for seismic analysis to assess the isolation effect especially at the site condition. The design response spectra [16] of this selected earthquake for fixed and base isolated conditions are shown in Fig. 4.

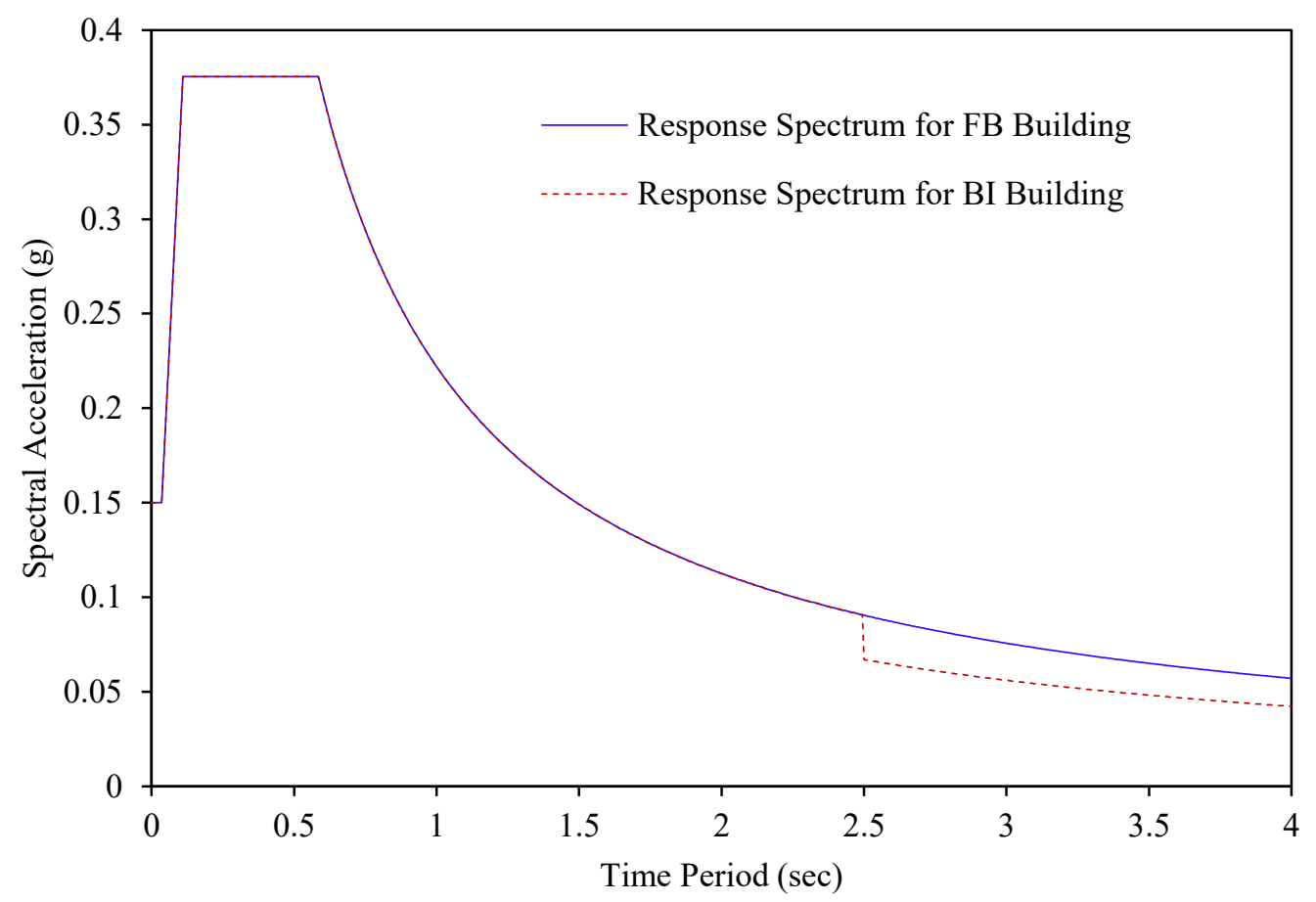

Fig. 4: Response spectra of the selected earthquake.

The dynamic equation for the building super structure after the bearing insertion can be designated $[2,10]$ by means of in Eqn. (4).

$$
[M]\left\{\ddot{y}+\ddot{y}_{b}\right\}+[C]\{\dot{y}\}+[K]\{y\}=-[M]\left[T_{g}\right]\left\{\ddot{y}_{g}\right\}
$$

where, $[C]$ is damping matrix; $[K]$ is stiffness matrix and $[M]$ is mass matrix of the building superstructure for respective DOF at the slabs. $\left[T_{g}\right]$ is the coefficient matrix of earthquake effect. In addition, $\{y\}=\left[y_{x}, y_{y}, y_{z}\right]^{T}$ is the displacement vector at the structure's floor levels associated with the base mass; $\left\{y_{b}\right\}=\left[\mathrm{y}_{b x}, y_{b y}, y_{b z}\right]^{T}$ is the base displacement vector relative to the ground and $\left\{\ddot{y}_{g}\right\}$ is the ground acceleration vector.

This analysis technique uses the design response spectra engendered from seismic excitation of FB buildings. However, for BI buildings, the design response spectrum has been adapted to cope with the damping offered by bearing devices by using a composite spectrum. The B factor has been used to reduce the 5\% damped composite spectrum in the isolated modes (Fig. 4). 
The motion equations have been transferred for the dynamic analysis into a normal coordinate system. Modal superposition technique is employed to perform the RSA. The values of modal superposition have been combined according to the complete quadratic combination (CQC) approach. The square root sum of the squares (SRSS) progression provides the directional combination of the modal values.

\subsection{Numerical Study}

All sixteen (16) base isolated buildings of varying height comprising the four variations of HDRB isolation systems as well as four fixed based buildings of different elevations have been investigated. Each isolation system is incorporated to satisfy the stiffness and strength properties essential for the assessment. The HDRB systems have been designed for $1.5 \mathrm{~s}, 2.0 \mathrm{~s}, 2.5 \mathrm{~s}$ and $3.0 \mathrm{~s}$ effective isolation periods.

The properties of HDRB are functions of shear strain applied with around $3 \mathrm{MPa}$ shear modulus for very little strains dropping to $0.75 \mathrm{MPa}$ at $250 \%$ strain. Yield displacements, $\Delta \mathrm{y}$, is chosen as $0.05 \sim 0.10$ times the rubber thickness. Relying on the individual isolation periods, the damping percentage ranges in between $15 \% \sim 19 \%$.

Dynamic analyses of the three-dimensional (3D) buildings are carried out with consideration for the associated nonlinearities. After assigning stiffness values to the isolators, all the isolated structures have been analyzed in SAP2000 [11] and the results are critically evaluated.

\section{RESULTS AND DISCUSSION}

Due to the additional flexibility of the superstructure, the structural behavior of the base-isolated structure changes. The following sections describe the viability of bearing incorporation as well as improvement of structural responses by applying various HDRB systems.

\subsection{Viability of HDRB Incorporation}

The fundamental time periods of the selected FB buildings for isolation are $\leq 1.0$ second, which can be considered suitable and within reasonable limits [12]. The horizontal base displacements of the buildings, as per site requirements, are within the allowable limit of $200 \mathrm{~mm}$. Furthermore, the lateral shear force imposed by wind is clearly less than $10 \%$ of building weight [17], as required. From the static analysis of the fixed base building, it is observed that the maximum wind-induced shear experienced by the 10-story building is around $2.11 \%$ of the building weight. This tendency is closely followed by all other scenarios analyzed. Thus, isolators could be inserted at the structural base as an alternative to the conventional fixed base strategy.

The isolators' designed parameters need to meet two conditions: the isolation bearings are capable of securely withstanding the imposed loads and overall performance of the bearings has to be satisfactory. The ability of isolation bearings to carry the loads has been checked using factors of safety (FS). As FS is more than 1.0, the ability of the HDRBs for carrying loads safely can be considered satisfactory. The performance of BI buildings is assessed for both the design basis earthquake (DBE) and maximum credible earthquake (MCE) choosing soil profile $\mathrm{S} 3$ with the zone factor $\mathrm{Z}=0.15$. The assessments for earthquake levels, DBE and MCE have been found to be satisfactory. Each and every value of maximum displacements remains within the allowable isolator design static displacement $(292.61 \mathrm{~mm})$ under the MCE. Therefore, the properties of the HDRB devices maintain good agreement and can be reasonably employed. 


\subsection{Moment Behavior}

Reduction of seismic damage by inserting a bearing device includes both the structural along with the non-structural systems of buildings. Decreasing a building's nonstructural damage requires reducing the floor moment. As a lateral force, an important response indicator of $\mathrm{FB}$ and $\mathrm{BI}$ buildings is the moment in superstructure. The distribution of moment force along the height of the superstructure in base-isolated buildings indicates the enhancement of the behavior of the structure. Figure 5 shows the improvement of moments for different buildings. It has been seen that moment might be overestimated if HDRB is not incorporated at the structural base.

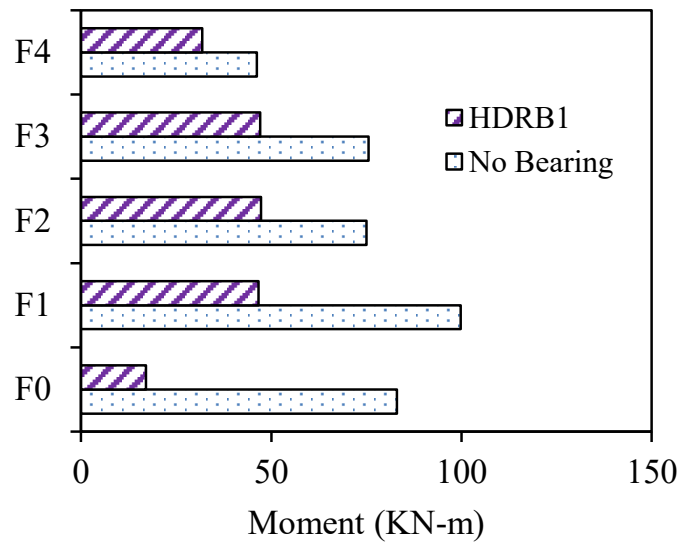

(a) 4 story building

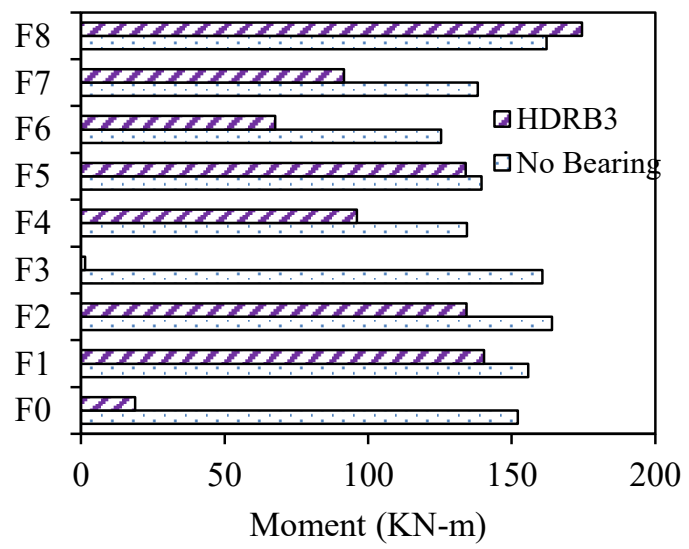

(c) 8 story building

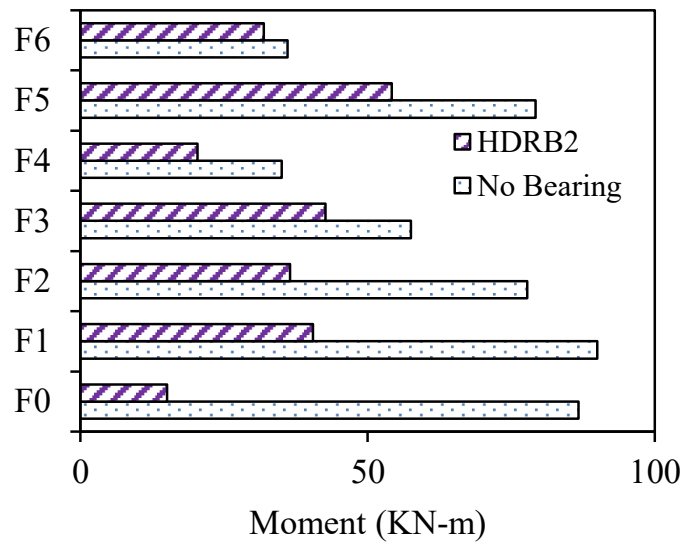

(b) 6 story building

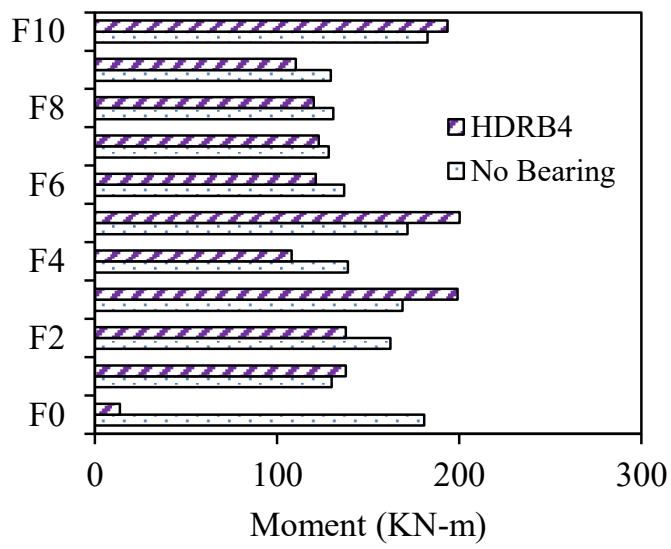

(d) 10 story building

Fig. 5: Moment distribution of FB and BI buildings.

Crucial reduction of moment of mostly $31 \sim 55 \%$ at the upper stories (Fig. 6) indicates the improvement of structural responses leading to economic design of structure. Structural safety against seismic excitation can also be obtained following such force reduction of structural members. Especially for the bottom stories, the decrement is very momentous, as clearly shown in Table 3. Nevertheless, for high-rise buildings, especially for a 10 story case, greater moment values are seen for a few floors and less reduction for some other floors due to the variation in mass participation and nonlinear dynamics of the structural system. This is the gorgeousness of HDRB which attracts the construction industry to keep up with this innovative technique for building construction. 
A high damping bearing device can be chosen to reduce the forces, moments, and relative displacement of structural elements that can lead to economic design.

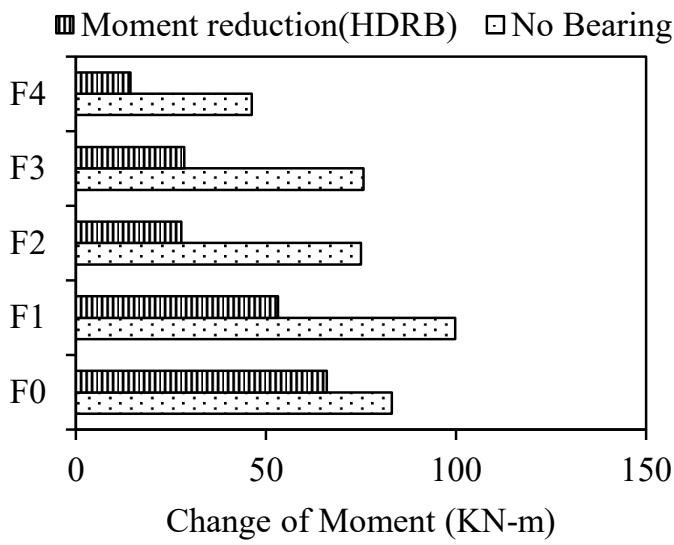

(a) 4 story building

m Moment reduction(HDRB) $\square$ No Bearing

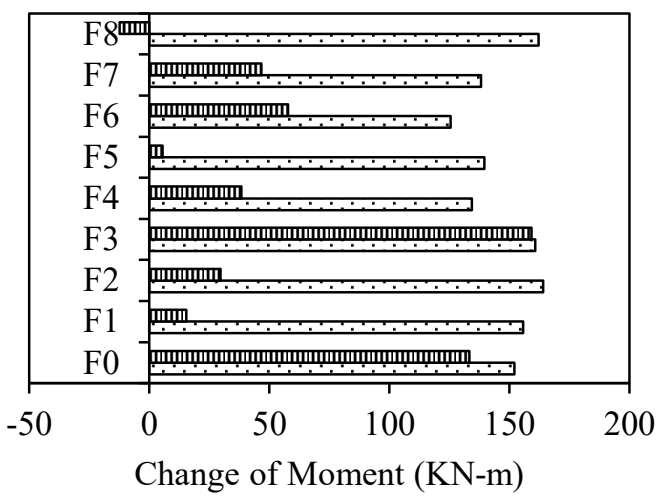

(c) 8 story building m Moment reduction(HDRB) $\square$ No Bearing

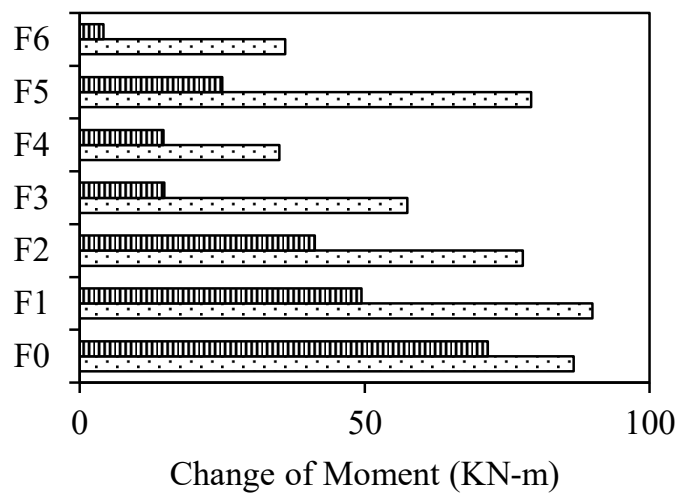

(b) 6 story building

血 Moment reduction(HDRB) $\square$ No Bearing

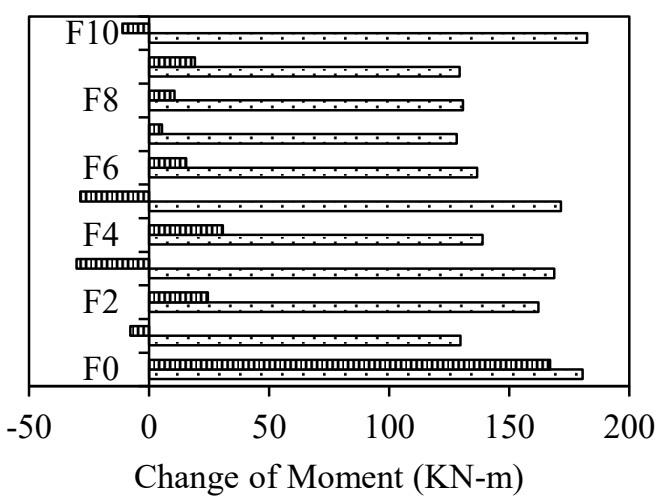

(d) 10 story building

Fig. 6: Change of moment after HDRB isolation.

Table 3: Percentage reduction of moment by using HDRB.

\begin{tabular}{ccccc}
\hline \multirow{2}{*}{$\begin{array}{c}\text { Floor } \\
\text { level }\end{array}$} & \multicolumn{4}{c}{ Reduction of Moment (\%) } \\
\cline { 2 - 5 } & 4-story & 6-story & 8 -story & 10-story \\
\hline F0 & 79.40 & 82.64 & 87.59 & 92.43 \\
F1 & 53.29 & 54.98 & 9.87 & -6.01 \\
F2 & 36.98 & 53.06 & 18.13 & 15.12 \\
F3 & 37.64 & 25.82 & 99.10 & -17.87 \\
F4 & 31.05 & 41.94 & 28.51 & 22.21 \\
F5 & --- & 31.57 & 3.97 & -16.67 \\
F6 & --- & 11.60 & 46.13 & 11.32 \\
F7 & --- & --- & 33.77 & 4.23 \\
F8 & --- & --- & -7.60 & 8.20 \\
F9 & --- & --- & --- & 14.76 \\
F10 & --- & --- & --- & -6.01 \\
\hline
\end{tabular}

\subsection{Displacement Behavior}

For the fixed base structures, the tendency of inertia is to keep structures in place at the time of ground excitation resulting in large displacements at different stories in 
structures. Nonetheless, for base isolated structures, displacement occurs almost uniformly in the whole upper structure and the displacement at the base remains within acceptable limits. As the relative displacement of adjacent stories is minimal, such structures can resist high seismic tremors in a safe and efficient manner against seismic ground excitation.

The key points in investigating the dynamic responses of base-isolated buildings are the base displacements and story forces. Here, base displacement indicates the superstructure translation in isolation interface. The analyses reveal that the structure is shifted by $87.15 \mathrm{~mm} \sim 130.15 \mathrm{~mm}$ while the bearing is inserted. For BI buildings, the superstructure gets such significant displacement even at base namely, at isolation interface. But in case of FB structures, base displacement is zero and the floor displacements vary nonlinearly commencing from zero to maximum at top story. Conversely, the variation of horizontal translation in between floor to floor for BI buildings are not substantial (below 3\%), ensuring almost uniform shape of distribution.

Figure 7 plots the variation of horizontal translation of different number of stories using a unique type of high damping rubber bearing HDRB1. It is logical that with increase of building elevation, the displacements at bearing interface are gradually increased. The 4-story building shows around 33.04\% less shift than that of the 10-story building. However, the rate of increment from 8 - to 10 -story structure is $10 \%$, which is less than the rate of increment for lower story buildings of $16 \sim 17 \%$. The observation suggests that the pattern of results is comparatively oblivious to the structural period and so representative HDRB1 induced responses are described. The higher the isolator period, the larger the displacement and lesser the equivalent viscous damping. Again, to compare the structural response for different bearings, the scaling of the selected ground motions and the choice of the damping reduction factor are of great importance. If both are addressed well, the model developed could be a very useful tool for base isolated buildings, especially in the preliminary stage of structural design.

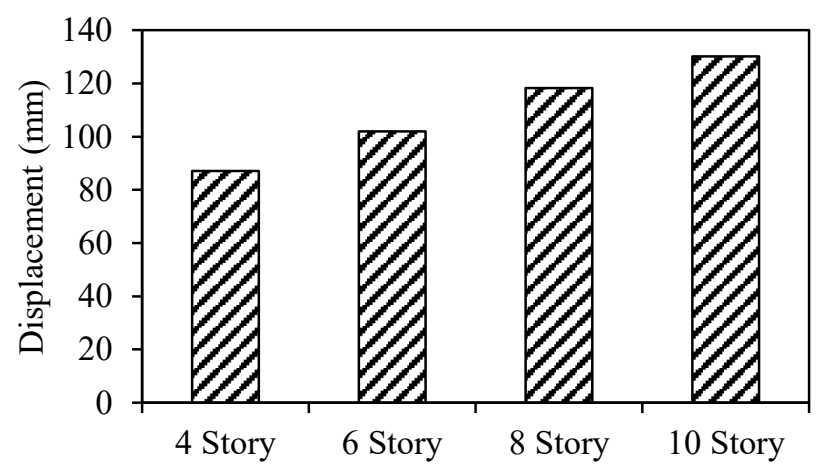

Fig. 7: Superstructure Displacement of BI buildings at bearing interface.

\subsection{Inertia Behavior}

The shear force of buildings is maximum at base level, which is computed from the concurrent summation of maximum inertia forces at each floor above bearing level. The modal inertia force is a function of structural mass, spectral acceleration, and the participation factor at the respective level. The inertia forces at the respective floor denote the design shears at each level, leading to computation of base shear as well as overturning moment of the building. 
The distribution of inertia has been computed as the effective inertia height, $\mathrm{H}_{\mathrm{C}}$ which is the ratio of highest overturning moment by the product of design base shear and building height. This effective height indicated linear inertia distribution when the value is 0.5 and triangular for 0.67 magnitude. The centroids of inertia loads are at half and twothird of the buildings' height respectively. For $\mathrm{H}_{\mathrm{C}}$ equaling to 1.0, distribution of inertia forces concentrates at the top story. Figure 8 plots these distributions for four building configurations comprising four types of HDRB as well as fixed based buildings in terms of normalized values. It is observed that without bearing the effective height of building inertia is around 0.5 tending to be triangularly distributed. Accordingly, it generates a conformist moment for most of the buildings. For the BI buildings, the effective inertia height $\mathrm{H}_{\mathrm{C}}$ ranges between the two-thirds of building elevation (Fig. 8) showing triangular distribution concentrating at top story level except the low-rise building. This trend is followed by all types of HDRB. It is also revealed that in general, the lengthier the isolation period the more flexible the structures are.

曰No Bearing $₫$ HDRB1 $\llbracket$ HDRB2 四HDRB3 目HDRB4

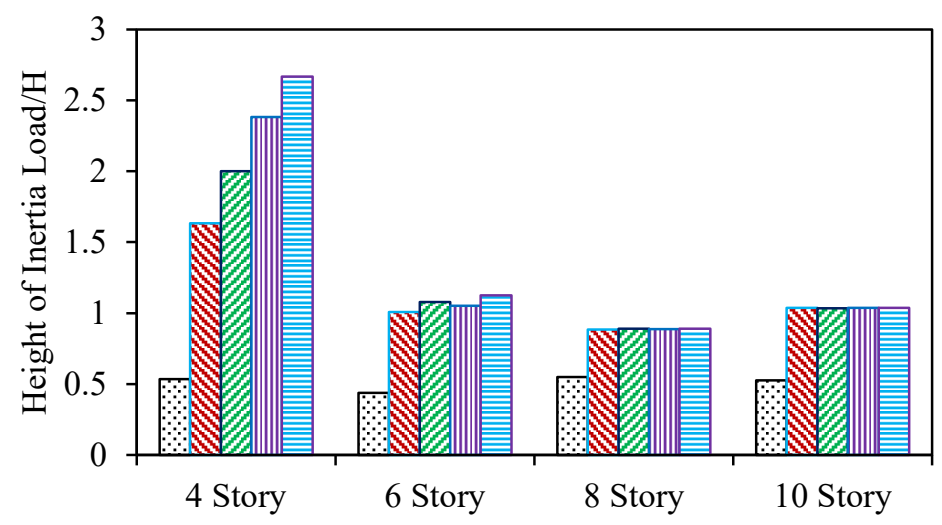

Fig. 8: Normalized height of inertia force for different buildings.

This behavior is reasonable because of the fundamental mode shape produced by the bearing devices. Unfortunately for the 4-story building, the HDRBs provide effective inertia height exceeding building height by a large extent as 1.63 2.67 times. The tendency of effective inertia height exceedance increases with the increase of the isolator period. It indicates the moment distribution has very high shear at the top story. The phenomena of increasing top story shear and moment is also supported by the effective inertial height where the distribution offers a high moment corresponding to the shear. Obviously, it confirms the kicking back of building at the base.

The consequences of the analyses disclose that the high damping bearing device is expected to diminish the corresponding moments at different floor levels, the superstructure's relative displacement as well as upsurge to the effective inertia height. The superstructure-foundation contact part acts as a passive control system, through the HDRB device, and can be the main reason behind the stability of the building structures in seismic-prone areas. 


\section{CONCLUDING REMARKS}

Subsequent findings have been outlined from the analyses conducted in the present study.

- Anticipated base isolation technique is intended to draw attraction of using the high damping rubber bearing at structural base in seismic-prone areas as a suitable alternative to structural retrofitting.

- The moment will be highly overestimated by $31 \sim 55 \%$ if the bearing is not incorporated in building base. Reduction of moments allow the structures to withstand comparatively high seismic tremors in a safe and efficient manner.

- For HDRB isolated structures, the superstructures experience significant lateral shift as $87.15 \mathrm{~mm} \sim 130.15 \mathrm{~mm}$ due to structural flexibility. The increase of superstructure shift is $16 \sim 17 \%$ for low-rise but around $10 \%$ between high-rise buildings. The relative floor displacement remains below 3\% of adjacent floor.

- The lengthier the isolation period, the more flexible the structures are.

- The effective inertia height for the BI buildings remains between two-thirds of building elevation showing triangular distribution concentrating to the top story.

- The distribution of effective inertia offers high moment corresponding to the shear at top story. Obviously, it confirms the kicking back of the building at the base.

- The superstructure-substructure contact part acts as a passive control system, through the HDRB device, and might be the main reason behind the stability of these structures in active seismic zones.

- High damping bearing device can reduce the forces, moments and relative displacement of structural members which can lead to economic design and structural safety against seismic excitation.

\section{ACKNOWLEDGEMENT}

The authors gratefully acknowledge the Project 2017-212-Eng, Deanship of Scientific Research (DSR), Imam Abdulrahman Bin Faisal University (IAU) for successful completion of the study.

\section{REFERENCES}

[1] Ismail M, Rodellar J, Ikhouane F. (2010) An innovative isolation device for aseismic design. Engineering Structures, 32:1168-83.

[2] Islam ABMS, Hussain RR, Jumaat MZ, Rahman MA. (2013) Nonlinear dynamically automated excursions for rubber-steel bearing isolation in multi-storey construction. Automation in Construction, 30:265-75.

[3] Islam ABMS, Jameel M, Jumaat MZ, Rahman MM. (2013) Optimization in structural altitude for seismic base isolation at medium risk earthquake disaster region. Disaster Advances, 6:23-34.

[4] Dicleli M, Buddaram S. (2007) Comprehensive evaluation of equivalent linear analysis method for seismic-isolated structures represented by sdof systems. Engineering Structures, 29:1653-63.

[5] Islam ABMS, Jameel M, Uddin MA, Jumaat MZ. (2012) Competent Building Elevation for Incorporating Base Isolation in Aseismic Structure. Procedia Engineering, 50:882-92.

[6] Tornello ME, Sarrazin M. (2012) Base-isolated building with high-damping spring system subjected to near fault earthquakes. Earthquakes and Structures, 3:315-40. 
[7] Bhuiyan AR, Okui Y, Mitamura H, Imai T. (2009) A rheology model of high damping rubber bearings for seismic analysis: Identification of nonlinear viscosity. International Journal of Solids and Structures, 46:1778-92.

[8] Markou AA, Manolis GD. (2016) Mechanical models for shear behavior in high damping rubber bearings. Soil Dynamics and Earthquake Engineering, 90:221-6.

[9] Alhan C, Gazi H, Kurtuluş H. (2016) Significance of stiffening of high damping rubber bearings on the response of base-isolated buildings under near-fault earthquakes. Mechanical Systems and Signal Processing, 79:297-313.

[10] Islam ABMS, Hussain RR, Jameel M, Jumaat MZ. (2012) Non-linear time domain analysis of base isolated multi-storey building under site specific bi-directional seismic loading. Automation in Construction, 22:554-66.

[11] CSI. (2004) Linear and nonlinear static and dynamic analysis of three-dimensional structures Computer \& Structures Inc. SAP 2000. Berkeley (CA).

[12] Kelly TE, Robinson WH, Skinner RI. (2006) Seismic Isolation for Designers and Structural Engineers: Robinson seismic Ltd.

[13] Islam ABMS, Ahmad SI, Jumaat MZ, Hussain RR, Rahman MA, Darain KM. (2014) Efficient design in building construction with rubber bearing in medium risk seismicity: case study and assessment. Journal of Civil Engineering and Management, 20:621-31.

[14] Cheng FY, Jiang H, Lou K. (2008) Smart structures: innovative systems for seismic response control: CRC Press.

[15] Uniform Building Code (UBC). (1997) Earthquake regulations for seismic isolated structures International conference of building officials. Whitter (CA,USA).

[16] Islam ABMS, Jameel M, Ahmad SI, Salman FA, Jumaat MZ. (2011) Engendering earthquake response spectra for Dhaka region usable in dynamic analysis of structures. Scientific Research and Essays, 6:3519-30.

[17] Deb S. (2004) Seismic base isolation-an overview. Current Science, 87:1426-30. 